\title{
Nitrogen utilization, nutrient digestibility, and excretion of purine derivatives in dairy cattle consuming rations containing corn milling co-products
}

\author{
A. M. Gehman and P. J. Kononoff ${ }^{1}$ \\ Department of Animal Science, University of Nebraska, Lincoln 68583-0908
}

\begin{abstract}
The objectives of this experiment were to determine the effects of feeding a combination of modified wet distillers grains with solubles (WDGS) and wet corn gluten feed (WCGF) on nutrient digestion, purine derivative excretion, and $\mathrm{N}$ utilization. Multiparous $(\mathrm{n}=20)$ and primiparous $(\mathrm{n}=20)$ cows were arranged in a replicated $5 \times 5$ Latin square with 21 -d periods. Animals were fed one of 5 treatment diets during each period: 1 ) $0 \%$ co-products (control); 2) 15\% WDGS (15WDGS); 3) $15 \%$ WCGF (15WCGF); 4) $7.5 \%$ WDGS and $7.5 \%$ WCGF (15MIX); and 5) 15\% WDGS and 15\% WCGF (30MIX; dry matter basis). A portion of forages, corn, and soy-based protein was replaced with WDGS, or WCGF, or both. Dry matter intake was greater for 15WDGS $(25.1 \mathrm{~kg} / \mathrm{d})$ and 30MIX $(25.5 \mathrm{~kg} / \mathrm{d})$ than for control $(22.4 \mathrm{~kg} / \mathrm{d}), 15$ WCGF $(23.2 \mathrm{~kg} / \mathrm{d})$, or $15 \mathrm{MIX}$ $(23.5 \mathrm{~kg} / \mathrm{d})$. Dry matter digestibility was greatest for 15WCGF and 30MIX (63.6 and 64.1\%, respectively) and least for 15WDGS (59.8\%), and neutral detergent fiber and $\mathrm{N}$ digestibility were greatest for 30MIX (50.7 and $68.6 \%$, respectively) and lowest for 15WDGS (41.3 and $61.5 \%$, respectively). Excretion of purine derivatives in urine was greater for co-product treatment diets than for control. Fecal N was greatest for 15WDGS compared with other treatment diets (311.0 vs. 263.3 $\mathrm{g} / \mathrm{d}$ ), whereas urinary $\mathrm{N}$ was greatest for 30MIX (330.0 $\mathrm{g} / \mathrm{d}$ ), intermediate for 15WCGF and 15MIX (319.3 and $320.5 \mathrm{~g} / \mathrm{d}$, respectively), and lowest for control and 15WDGS (308.5 and $312.2 \mathrm{~g} / \mathrm{d}$, respectively). Manure $\mathrm{N}$ (fecal + urinary $\mathrm{N}$ ) was greatest for 15WDGS, intermediate for 15MIX and 30MIX, and lowest for control and 15WCGF. Treatment diets did not differ in $4 \%$ fat-corrected milk production. Compared with the ration containing WDGS, the ration with a $30 \%$ mixture of WDGS and WCGF improved nutrient digestibility and $\mathrm{N}$ utilization with reduced manure $\mathrm{N}$ excretion and increased $\mathrm{N}$ retention. Thus, it appears feeding WDGS
\end{abstract}

Received July 29, 2009.

Accepted April 26, 2010.

${ }^{1}$ Corresponding author: pkononoff $2 @ u n l . e d u$ and WCGF in combination reduces some of the negative effects of feeding WDGS alone.

Key words: corn milling co-product, digestibility, nitrogen utilization, purine derivative

\section{INTRODUCTION}

Wet distillers grains with solubles (WDGS) is a co-product of the dry milling process and includes the bran, germ, oil, and gluten from the corn grain (Bothast and Schlicher, 2005). Wet corn gluten feed (WCGF) is a product of the wet milling process and includes the bran and steep (Bothast and Schlicher, 2005). Both feedstuffs contain highly digestible corn fiber and are high in CP (30 and 23\% of DM for WDGS and WCGF, respectively; Kelzer, 2008). Because the corn oil is not fractionated out during dry milling, WDGS contains a higher concentration of ether extract (EE) compared with WCGF (14.2 vs. 5.1\% of DM; Kelzer, 2008). Ivan et al. (2004) demonstrated that the concentration of RUP in WCGF (5\% of CP) was lower than WDGS ( $43 \%$ of $\mathrm{CP}$ ). Although many dairy nutritionists routinely include corn milling co-products such as WDGS or WCGF in rations for lactating dairy cows, inclusion levels of these products are often low $(<10 \%$ of DM). Rations high in EE, specifically unsaturated fat found in WDGS (Kelzer, 2008), may negatively affect NDF digestibility (Oldick and Firkins, 2000) and may cause milk fat depression (Harvatine and Allen, 2006). In addition, replacing feedstuffs low in $\mathrm{CP}$, such as corn grain or silage, with co-products high in $\mathrm{CP}$ may result in rations that are higher in $\mathrm{CP}$, potentially increasing $\mathrm{N}$ excretion (Broderick, 2003; Groff and Wu, 2005). Adding WCGF to a ration with WDGS may result in a ration with lower EE and more RDP, potentially allowing for greater total inclusion of co-products. Consequently, dairy producers may be able to increase energy intake and minimize $\mathrm{N}$ excretion by cows by taking advantage of complementary nutritional properties of WDGS and WCGF while reducing inputs of corn, soy-based protein, and forages.

Nutritional methods that maximize the supply of MP should attempt to manipulate RUP and microbial CP (MCP) synthesis (NRC, 2001). Digestibility of RUP 
contained in WDGS has also been shown to be high (93.1\% of CP; Kelzer, 2008). The digestible fiber from the co-products may supply the ruminal microbes with readily fermentable energy and may promote $\mathrm{MCP}$ synthesis (Calsamiglia et al., 2008). Microbial protein has an AA profile that is a close match to the animal's requirements and is believed to be highly digestible (Clark et al., 1992; NRC, 2001). The objectives of this experiment were to explore the potential of complementary effects of including both WDGS and WCGF in rations for lactating dairy cows and to determine the effects of feeding high levels of corn milling co-products on nutrient digestibility, $\mathrm{N}$ utilization, purine derivative excretion, and production.

\section{MATERIALS AND METHODS}

\section{Animals and Experimental Treatment Diets}

Twenty primiparous and 20 multiparous Holsteins averaging (mean $\pm \mathrm{SD}$ ) $631 \pm 87 \mathrm{~kg}$ of $\mathrm{BW}$ and $93 \pm$ 29 DIM were used in this experiment. Animals were blocked by parity and production and assigned to 1 of 8 replicated $5 \times 5$ Latin squares with 21 -d periods. Animals consumed one of 5 treatment diets during each period. Treatment diets were: 1) $0 \%$ co-products (control); 2) 15\% of DM WDGS (15WDGS); 3) 15\% of DM WCGF (15WCGF); 4) $7.5 \%$ of DM WDGS and $7.5 \%$ of DM WCGF (15MIX); and 5) $15 \%$ of DM WDGS and $15 \%$ of DM WCGF (30MIX). Ration ingredient composition is shown in Table 1. Weekly loads of WDGS were received from Platte Valley Fuel Ethanol LLC (Central City, NE) and loads of WCGF (Sweet Bran) were received from Cargill Inc. (Blair, NE) and stored in commodity bays. The WDGS used in this experiment was a modified WDGS composed of dry and partially dry distillers grains with solubles, with higher DM than commonly observed for WDGS (Schingoethe et al., 1999). Rations were formulated to be similar in $\mathrm{CP}, \mathrm{ME}$, and MP based on the Cornell-Penn-Miner model (Boston et al., 2000). The control ration was formulated to be similar to a dairy diet fed in the Great Plains of the United States. This ration did not contain any corn milling co-products and largely comprised corn silage, alfalfa silage and hay, ground corn, and soybean meal. Given the high concentration of NDF and CP contained in WDGS and WCGF, they largely replaced the alfalfa silage and hay as well as soybean meal and bypass soy. A portion of ground corn was also replaced. Urea was removed from all treatment diets containing co-products. Because of the high fat content of WDGS, tallow was removed from treatment diets containing WDGS. Additional brome hay was added to treatment diets with co-products to achieve similar CP to control and to increase the concentration of effective fiber.

Cows were milked twice daily at 0730 and $1930 \mathrm{~h}$. Cows were housed in a tie-stall barn and fed once daily for $105 \%$ ad libitum intake. All experimental animals were treated with bST (Posilac, Monsanto Co., St. Louis, MO) on $\mathrm{d} 1$ and every $14 \mathrm{~d}$ thereafter for the duration of the experiment. All procedures were approved by the University of Nebraska-Lincoln Animal Care and Use Committee.

\section{Sample Collection and Analysis}

$B W, B C S$, and Milk Composition. Body weight and BCS (1 to 5 scale) were measured on d 19 and 20 of each period. Body condition score was measured by a single trained individual. The scoring method used was similar to Wildman et al. (1982) but differed slightly because it was reported to the quarter point. Milk production was measured daily and milk samples were collected during 4 consecutive milkings on d 19 and 20 and were preserved using 2-bromo-2-nitropropane-1,3 diol. Daily DMI and milk yield were averaged for d 14 to 20 of each period. Milk samples were analyzed by Heart of America DHIA (Manhattan, KS) for fat, true protein, and MUN (AOAC, 2000) using a B2000 Infrared Analyzer (Bentley Instruments, Chaska, MN).

Feed, Urine, and Fecal Samples. Total mixed rations and feedstuffs were sampled on d 19 and 20 of each period. The Penn State Particle Separator was used to measure particle size of TMR as described by Heinrichs and Kononoff (2002). Feed samples were dried for $48 \mathrm{~h}$ at $55^{\circ} \mathrm{C}$ in a forced air oven, ground to pass through a 1-mm screen (Wiley Mill, Arthur A. Thomas Co., Philadelphia, PA), and composited by sample for each period. Feed samples were analyzed for DM and ash (AOAC, 2000), N (Leco, FP-528, Leco Corp, St. Joseph, MI), and ADF and NDF (Ankom Fiber Analyzer, Ankom Technology, Fairport, NY). Heat-stable

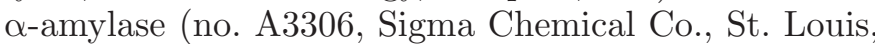
$\mathrm{MO})$ was included in the NDF procedure $(0.5 \mathrm{~mL} / 0.50$ $\mathrm{g}$ of sample). Additionally, TMR were analyzed for starch (Megazyme Total Starch Assay, Bray, Ireland) and EE (AOAC, 2000).

Fecal and urine samples were collected for all cows at 0600 and $1800 \mathrm{~h}$ on d 17 to 20 of each period. Feces were sampled from the rectum and urine was sampled during urination with stimulation. Fecal samples were composited for individual cows in each period, dried at $55^{\circ} \mathrm{C}$ in a forced-air oven, and ground to pass through a 1-mm screen. Ground samples were analyzed for DM, $\mathrm{N}$, ash, NDF, ADF, and EE using the same procedures described for feed. Urine was acidified to $\mathrm{pH}<4$ using $5 \mathrm{M} \mathrm{HCl}$ and frozen $\left(-20^{\circ} \mathrm{C}\right)$. Urine samples were 
Table 1. Ingredient composition of experimental diets ${ }^{1}$

\begin{tabular}{|c|c|c|c|c|c|}
\hline Ingredient, $\%$ of DM & Control & 15WDGS & $15 \mathrm{WCGF}$ & 15MIX & $30 \mathrm{MIX}$ \\
\hline Wet distillers grains with solubles & - & 15.0 & - & 7.5 & 15.0 \\
\hline Wet corn gluten feed & - & - & 15.0 & 7.5 & 15.0 \\
\hline Corn silage & 28.0 & 25.5 & 23.0 & 24.3 & 24.0 \\
\hline Alfalfa haylage & 9.8 & 9.0 & 8.0 & 8.5 & 3.5 \\
\hline Alfalfa hay & 9.8 & 9.0 & 8.0 & 8.5 & 3.5 \\
\hline Brome hay & 3.5 & 3.0 & 3.0 & 3.0 & 6.0 \\
\hline Ground corn & 17.5 & 13.5 & 14.5 & 14.0 & 9.5 \\
\hline Soybean meal & 6.0 & 3.5 & 5.5 & 4.5 & 3.2 \\
\hline By-pass soy $^{2}$ & 6.0 & 4.0 & 4.5 & 4.3 & 3.5 \\
\hline Cottonseed & 6.0 & 5.5 & 5.5 & 5.5 & 4.0 \\
\hline Soybean hulls & 10.0 & 10.2 & 10.0 & 10.1 & 10.0 \\
\hline Urea & 0.24 & - & - & - & - \\
\hline Tallow & 1.0 & - & 1.0 & 0.5 & - \\
\hline Vitamin $\mathrm{ADE}^{3}$ & 0.12 & 0.12 & 0.12 & 0.12 & 0.12 \\
\hline Magnesium oxide & 0.24 & 0.24 & 0.24 & 0.24 & 0.24 \\
\hline Trace mineral ${ }^{4}$ & 0.04 & 0.04 & 0.04 & 0.04 & 0.04 \\
\hline Sel-plex $1000^{5}$ & 0.02 & 0.02 & 0.02 & 0.02 & 0.02 \\
\hline Vitamin E & 0.02 & 0.02 & 0.02 & 0.02 & 0.02 \\
\hline Limestone & 1.0 & 0.9 & 1.0 & 1.0 & 1.5 \\
\hline Salt & 0.12 & 0.12 & 0.18 & 0.15 & 0.2 \\
\hline Sodium bicarbonate & 0.5 & 0.5 & 0.5 & 0.5 & 0.8 \\
\hline
\end{tabular}

${ }^{1}$ Control $=0 \%$ of DM co-products; 15 WDGS $=15 \%$ of DM wet distillers grains with solubles (WDGS); $15 \mathrm{WCGF}=15 \%$ of DM wet corn gluten feed (WCGF); $15 \mathrm{MIX}=7.5 \%$ of DM WDGS $+7.5 \%$ of DM WCGF; $30 \mathrm{MIX}=15 \%$ of DM WDGS $+15 \%$ of DM WCGF .

${ }^{2}$ LignoTech (Overland Park, KS).

${ }^{3}$ Assuming daily intake to be $22.5 \mathrm{~kg}$, formulated to supply approximately $120,000 \mathrm{IU} / \mathrm{d}$ of vitamin A, 24,000 $\mathrm{IU} / \mathrm{d}$ of vitamin $\mathrm{D}$, and $800 \mathrm{IU} / \mathrm{d}$ of vitamin $\mathrm{E}$ in the total ration.

${ }^{4}$ Formulated to contain $0.05 \% \mathrm{Ca}, 0.04 \% \mathrm{Fe}, 0.03 \% \mathrm{Mn}, 600 \mathrm{mg} / \mathrm{kg}$ of Cu, $40 \mathrm{mg} / \mathrm{kg}$ of Co, and $80 \mathrm{mg} / \mathrm{kg}$ of I in the total ration.

${ }^{5}$ Alltech Inc. (Nicholasville, KY).

thawed and composited by volume for each cow during each period. Urine samples were analyzed for $\mathrm{N}$ (Leco, FP-528, Leco Corp). Urinary creatinine and purine derivatives (PD) were analyzed by HPLC (Waters Corp., Milford, MA) according to the procedures of Shingfield and Offer (1999). Urinary creatinine has been validated as a marker to estimate urine volume (Valadares et al., 1999; Leonardi et al., 2003). Urinary PD, namely allantoin, uric acid, xanthine, and hypoxanthine, are widely used to estimate MCP flow to the duodenum (Gonda, 1995; Shingfield and Offer, 1998). In calculating urine volume, creatinine output was assumed to average 28 $\mathrm{mg} / \mathrm{kg}$ of BW as estimated by Whittet (2004). The ratio of urinary $\mathrm{PD}$ to creatinine was used to estimate relative differences in MCP production (Shingfield and Offer, 1998). Based on estimates of urinary excretion of PD, MCP supply was calculated according to Chen and Gomes (1992).

Nutrient digestibility was estimated using indigestible ADF as a marker (Huhtanen et al., 1994). The TMR and fecal samples were weighed into Dacron bags $(5 \times$ $10 \mathrm{~cm}, 50 \mu \mathrm{m}$ pores; no. R510, Ankom Technology) and incubated in the rumen of a lactating fistulated cow fed a diet containing $60 \%$ forage and $40 \%$ concentrate for 12 d. Apparent digestibility of nutrients was estimated based on the concentration of indigestible ADF in the
TMR and feces, and $\mathrm{N}$ excretion in feces was calculated from $\mathrm{N}$ digestibility and $\mathrm{N}$ intake. Manure $\mathrm{N}$ excretion was total of fecal and urinary $\mathrm{N}$ excreted. Total digestible nutrients (TDN) was calculated based on nutrient digestibilities obtained for each cow and treatment diet combination to account for the effect of intake on digestibility. Net energy for lactation was calculated based on TDN as described in NRC (2001). Energy balance was calculated as the difference between $\mathrm{NE}_{\mathrm{L}}$ intake (Mcal/d) and $\mathrm{NE}_{\mathrm{L}}$ output in milk and $\mathrm{NE}_{\mathrm{L}}$ required for maintenance $\left(0.08 \mathrm{Mcal} / \mathrm{BW}^{0.75}\right)$.

\section{Statistical Analysis}

Animal data were analyzed as a replicated $5 \times 5$ Latin square with model effects for parity, square within parity, period within square by parity, and treatment as fixed effects and cow within square as a random effect. The MIXED procedure of SAS (version 9.1; SAS Institute, 2004) was used. The linear model for this experiment is written as follows:

$$
\begin{aligned}
\mathrm{Y}_{\mathrm{ijkmn}}=\mu+\mathrm{P}_{\mathrm{i}} & +\mathrm{C}(\mathrm{S})_{\mathrm{jk}}+\mathrm{S}(\mathrm{P})_{\mathrm{ik}}+\mathrm{R}(\mathrm{SP})_{\mathrm{ikm}} \\
& +\mathrm{T}_{\mathrm{n}}+\varepsilon_{\mathrm{ijkmn}},
\end{aligned}
$$


Table 2. Chemical composition of feed ingredients ${ }^{1,2}(\mathrm{n}=10)$

\begin{tabular}{lcccccc}
\hline Nutrient, \% of DM unless noted & CS & AS & AH & Brome & WDGS & WCGF \\
\hline $\mathrm{DM}, \%$ & $36.7 \pm 4.8$ & $34.4 \pm 3.4$ & $91.5 \pm 0.8$ & $84.0 \pm 4.9$ & $49.4 \pm 3.1$ & $60.7 \pm 2.8$ \\
$\mathrm{OM}$ & $94.7 \pm 0.8$ & $83.4 \pm 7.4$ & $90.3 \pm 0.5$ & $92.2 \pm 0.7$ & $94.7 \pm 0.5$ & $94.2 \pm 0.2$ \\
$\mathrm{CP}$ & $10.1 \pm 0.6$ & $23.9 \pm 2.1$ & $25.1 \pm 1.7$ & $10.9 \pm 1.3$ & $31.5 \pm 1.2$ & $26.0 \pm 1.1$ \\
$\mathrm{NDF}^{3}$ & $40.4 \pm 2.1$ & $41.5 \pm 2.0$ & $41.0 \pm 1.7$ & $73.4 \pm 2.0$ & $45.8 \pm 3.8$ & $42.8 \pm 2.2$ \\
Starch $_{\text {Lignin }}$ & $35.6 \pm 2.4$ & - & - & - & $4.0 \pm 0.8$ & $9.5 \pm 0.8$ \\
Ether extract & $3.1 \pm 0.8$ & $7.8 \pm 0.7$ & $6.9 \pm 0.9$ & $5.4 \pm 2.3$ & $3.5 \pm 0.8$ & $1.6 \pm 0.8$ \\
\hline
\end{tabular}

${ }^{1} \mathrm{CS}=$ corn silage; $\mathrm{AS}=$ alfalfa silage; $\mathrm{AH}=$ alfalfa hay; brome $=$ brome hay; WDGS $=$ wet distillers grains with solubles; WCGF = wet corn gluten feed.

${ }^{2}$ Mean $\pm \mathrm{SD}$

${ }^{3}$ Determined without sodium sulfite.

where $\mathrm{Y}_{\mathrm{ijkmn}}$ is observation ijkmn; $\mu$ is the overall mean; $\mathrm{P}_{\mathrm{i}}$ is the fixed effect of parity i; $\mathrm{C}(\mathrm{S})_{\mathrm{jk}}$ is the random effect of cow $\mathrm{j}$ within square $\mathrm{k} ; \mathrm{S}(\mathrm{P})_{\mathrm{ik}}$ is the fixed effect of square $\mathrm{k}$ within parity $\mathrm{i}$; $\mathrm{R}(\mathrm{SP})_{\mathrm{ikm}}$ is period $\mathrm{m}$ within square $k$ by parity $i$; and $T_{n}$ is the fixed effect of treatment $n$. The residual terms $\varepsilon_{i j k m n}$ are assumed to be normally, independently, and identically distributed with variance $\sigma_{\text {e }}^{2}$. Significance was declared at $P$ $<0.05$ and trends at $P<0.10$. The PDIFF option of SAS was used to test treatment differences among least squares means, and all means presented are least squares means.

\section{RESULTS AND DISCUSSION}

\section{Feed Nutrient Composition and Particle Size}

Nutrient composition of individual feedstuffs and experimental treatment diets are listed in Tables 2 and 3, respectively. The $\mathrm{CP}$ content of WDGS and WCGF used in this experiment (32 and $26 \%$ of DM, respectively; Table 2) was similar to values published in NRC (2001) (30 and 24\% of DM, respectively). In contrast, NDF and EE content of WDGS (46 and 15\% of DM, respectively; Table 2) and WCGF (43 and $5 \%$ of DM, respectively; Table 2) used in this experiment were higher than values listed in NRC (2001) for WDGS (39 and 10\% of DM, respectively) and WCGF (36 and $3.5 \%$ of DM, respectively). Although differing from NRC (2001) values, the relative comparison between WDGS and WCGF remained, with WDGS having greater content of EE and $\mathrm{CP}$ and similar NDF compared with WCGF. The control and 15WCGF rations (Table 3) had the lowest NDF content (37.2 and $38.4 \%$ of DM, respectively), whereas 30MIX had the highest $(42.5 \%$ of DM). This was attributed to partial substitution of ground corn with WDGS and WCGF as well as additional brome hay added to 30MIX. Starch content of experimental treatments decreased with the partial replacement of corn with co-products. The highest starch concentration was observed in control $(24.0 \%$ of DM), with 15WDGS, 15WCGF, and 15MIX having intermediate values $(20.4,20.4$, and $19.9 \%$ of DM, respectively) and 30MIX having the lowest value (17.3\% of DM). Because the oil is not fractionated out during the dry milling process (Bothast and Schlicher, 2005), the inclusion of WDGS resulted in a higher concentration of $\mathrm{EE}$ in rations $(4.44,5.31$, and $5.15 \%$ of $\mathrm{DM}$ for control, 15WDGS, and 30MIX, respectively).

Estimates of ration particle size are listed in Table 3. There were minimal differences in particle size distribution among treatment diets. Particle size recommendations outlined by Heinrichs and Kononoff (2002) were based on experiments including corn silage- and alfalfa silage-based TMR at 50:50 forage:concentrate ratio. Using the Penn State Particle Separator, these authors suggest that rations should contain 2 to $8 \%$ on the top screen $(>19.0 \mathrm{~mm}), 30$ to $50 \%$ on the second screen ( 8.0 to $19.0 \mathrm{~mm}$ ), 30 to $50 \%$ on the third screen (1.18 to $8.0 \mathrm{~mm})$, and less than $20 \%$ in the bottom pan $(<1.18$ $\mathrm{mm}$ ). Rations fell within these ranges for particles $>19.0 \mathrm{~mm}$ and 1.18 to $8.0 \mathrm{~mm}$, but did not meet the minimum recommendation for particles 8.0 to $19.0 \mathrm{~mm}$. In addition, in all rations except 15WCGF more than $20 \%$ of the TMR was $<1.18 \mathrm{~mm}$. One of the concerns with replacing forages with nonforage fiber sources is the reduction in ration particle size and effective fiber and the resulting risk for acidosis, displaced abomasum, and milk fat depression (Pereira et al., 1999). In this experiment, rations with co-products appeared to have had a slightly finer particle size; however, there were no detected incidences of displaced abomasum or other digestive disorders, nor was milk fat synthesis (Table 4) affected by treatment diet. Forage NDF content ranged from $17 \%$ for $30 \mathrm{MIX}$ to $22 \%$ for control. The NRC (2001) recommends that rations $33 \%$ or greater NDF contain at least $15 \%$ forage NDF. This indicates that effective fiber was adequate for all treatment diets. 
Table 3. Chemical composition and particle size distribution of experimental rations $(\mathrm{n}=10)$

\begin{tabular}{|c|c|c|c|c|c|c|}
\hline \multirow[b]{2}{*}{ Item } & \multicolumn{5}{|c|}{$\operatorname{Diet}^{1}$} & \multirow[b]{2}{*}{ SEM } \\
\hline & Control & 15WDGS & 15WCGF & $15 \mathrm{MIX}$ & 30MIX & \\
\hline \multicolumn{7}{|c|}{ Chemical, $\%$ of DM unless noted } \\
\hline DM, \% & 57.8 & 55.2 & 56.5 & 54.8 & 55.8 & 1.6 \\
\hline $\mathrm{OM}$ & 92.3 & 92.6 & 92.4 & 92.6 & 92.5 & 0.1 \\
\hline $\mathrm{CP}$ & 19.9 & 19.9 & 19.8 & 19.9 & 20.7 & 0.3 \\
\hline $\mathrm{NDF}$ & 37.2 & 40.7 & 38.4 & 40.1 & 42.5 & 0.4 \\
\hline Starch & 24.0 & 20.4 & 20.4 & 19.9 & 17.3 & 0.3 \\
\hline Ether extract & 4.4 & 5.3 & 4.7 & 4.9 & 5.2 & 0.1 \\
\hline $\mathrm{NFC}^{2}$ & 31.8 & 27.7 & 30.5 & 28.6 & 25.2 & 0.4 \\
\hline \multicolumn{7}{|c|}{ Particle size distribution $^{3}$} \\
\hline$>19.0 \mathrm{~mm}$ & 7.1 & 7.0 & 6.8 & 7.9 & 6.5 & 0.4 \\
\hline $8.0-19.0 \mathrm{~mm}$ & 27.4 & 24.6 & 25.0 & 24.5 & 21.9 & 0.6 \\
\hline $1.18-8.0 \mathrm{~mm}$ & 43.8 & 45.3 & 49.3 & 45.9 & 47.4 & 0.6 \\
\hline$<1.18 \mathrm{~mm}$ & 21.7 & 23.1 & 18.9 & 21.7 & 24.2 & 0.4 \\
\hline
\end{tabular}

${ }^{1}$ Control $=0 \%$ of DM co-products; $15 \mathrm{WDGS}=15 \%$ of DM wet distillers grains with solubles (WDGS); $15 \mathrm{WCGF}=15 \%$ of DM wet corn gluten feed (WCGF); $15 \mathrm{MIX}=7.5 \%$ of DM WDGS $+7.5 \%$ of DM WCGF; $30 \mathrm{MIX}=15 \%$ of DM WDGS $+15 \%$ of DM WCGF.

${ }^{2} \mathrm{NFC}=100-(\mathrm{CP}+\mathrm{NDF}+$ ash + ether extract $)$.

${ }^{3}$ Proportion of TMR (as fed) retained on each screen of the Penn State Particle Separator.

\section{Nutrient Intake and Apparent Total Tract Digestibility}

Results for nutrient intake and digestibility are listed in Table 5. Compared with control, cows consuming 30MIX and 15WDGS had greater $(P<0.01)$ DMI, whereas 15WCGF and 15MIX were similar to control. Previous research with corn milling co-products demonstrated increased DMI when animals were fed WCGF at $40 \%$ of ration DM (Kononoff et al., 2006) and dry distillers grains with solubles up to $30 \%$ of ration DM (Janicek et al., 2008). Differences in concentration of energy in feed among treatment diets may have influenced DMI by affecting hypertonicity and osmolarity in the rumen, thereby inducing rumen distention and satiety with increased $\mathrm{NE}_{\mathrm{L}}$ concentration (Allen, 2000). Compared with control, DMI increased for animals consuming 15WDGS, which may have been attributable to reduced energy concentration in the feed $(1.32$ vs. $1.27 \mathrm{Mal} / \mathrm{kg}$ ) because $\mathrm{NE}_{\mathrm{L}}$ intake was similar. Compared with control, DMI was similar for 15WCGF and $15 \mathrm{MIX}$, reflecting similar $\mathrm{NE}_{\mathrm{L}}$ concentration in the feed; however, $\mathrm{NE}_{\mathrm{L}}$ intake was greater for 15WCGF than control whereas 15MIX was similar. This mechanism alone may not explain the greater DMI observed for 30MIX because $\mathrm{NE}_{\mathrm{L}}$ concentration was greater than control, resulting in greater $\mathrm{NE}_{\mathrm{L}}$ intake. In this case, other factors not identified, such as palatability, may have stimulated the increase in DMI when animals consumed 30MIX.

Total amounts of nutrients digested and apparent total tract nutrient digestibilities are listed in Table 5. Dry matter digestibility (DMD) was similar for

Table 4. Effects of feeding corn milling co-products on milk yield and composition

\begin{tabular}{lccccccc}
\hline & \multicolumn{7}{c}{ Diet $^{1}$} \\
\cline { 2 - 6 } Item & Control & 15WDGS & 15WCGF & 15MIX & 30MIX & SEM & $P$-value \\
\hline Milk, kg/d & $38.6^{\mathrm{a}}$ & $41.2^{\mathrm{b}}$ & $40.4^{\mathrm{ab}}$ & $41.9^{\mathrm{b}}$ & $41.8^{\mathrm{b}}$ & 1.1 & 0.02 \\
$4 \% \mathrm{FCM}, \mathrm{kg} / \mathrm{d}$ & 38.8 & 41.0 & 40.0 & 40.4 & 41.6 & 1.2 & 0.25 \\
Fat, \% & 4.02 & 4.00 & 4.00 & 3.84 & 3.84 & 0.09 & 0.12 \\
Fat, kg/d & 1.52 & 1.61 & 1.59 & 1.58 & 1.61 & 0.05 & 0.33 \\
Protein, \% & 2.99 & 3.04 & 3.02 & 3.03 & 3.04 & 0.03 & 0.54 \\
Protein, kg/d & $1.16^{\mathrm{a}}$ & $1.26^{\mathrm{b}}$ & $1.22^{\text {ab }}$ & $1.26^{\mathrm{b}}$ & $1.29^{\mathrm{b}}$ & 0.04 & 0.02 \\
$4 \% \mathrm{FCM} / \mathrm{DMI}$ & 1.75 & 1.70 & 1.79 & 1.77 & 1.63 & 0.05 & 0.10 \\
MUN, mg/dL & 14.4 & 14.4 & 14.2 & 14.6 & 14.7 & 0.3 & 0.42 \\
BW, kg & $629.3^{\mathrm{a}}$ & $641.8^{\mathrm{b}}$ & $639.3^{\mathrm{b}}$ & $639.5^{\mathrm{b}}$ & $640.5^{\mathrm{b}}$ & 10.0 & $<0.01$ \\
BCS & 3.12 & 3.12 & 3.15 & 3.12 & 3.17 & 0.07 & 0.78 \\
\hline
\end{tabular}

${ }^{\mathrm{a}, \mathrm{b}}$ Means within a row with different superscripts differ $(P<0.05)$.

${ }^{1}$ Control $=0 \%$ of DM co-products; 15WDGS $=15 \%$ of DM wet distillers grains with solubles (WDGS);

$15 \mathrm{WCGF}=15 \%$ of DM wet corn gluten feed (WCGF); $15 \mathrm{MIX}=7.5 \%$ of DM WDGS $+7.5 \%$ of DM WCGF;

$30 \mathrm{MIX}=15 \%$ of DM WDGS $+15 \%$ of DM WCGF . 
Table 5. Effects of feeding corn milling co-products on apparent total tract nutrient digestibility

\begin{tabular}{|c|c|c|c|c|c|c|c|}
\hline \multirow[b]{2}{*}{ Item } & \multicolumn{5}{|c|}{ Diet $^{1}$} & \multirow[b]{2}{*}{ SEM } & \multirow[b]{2}{*}{$P$-value } \\
\hline & Control & 15WDGS & 15WCGF & 15MIX & 30MIX & & \\
\hline \multicolumn{8}{|l|}{ Intake, $\mathrm{kg} / \mathrm{d}$} \\
\hline DM & $22.4^{\mathrm{a}}$ & $25.1^{\mathrm{bc}}$ & $23.2^{\mathrm{a}}$ & $23.5^{\mathrm{ab}}$ & $25.5^{\mathrm{c}}$ & 0.8 & $<0.01$ \\
\hline NDF & $8.4^{\mathrm{a}}$ & $10.2^{\mathrm{b}}$ & $8.9^{\mathrm{ac}}$ & $9.4^{\mathrm{c}}$ & $10.8^{\mathrm{b}}$ & 0.3 & $<0.01$ \\
\hline $\mathrm{N}$ & $0.72^{\mathrm{a}}$ & $0.80^{\mathrm{b}}$ & $0.73^{\mathrm{a}}$ & $0.75^{\mathrm{a}}$ & $0.84^{\mathrm{b}}$ & 0.02 & $<0.01$ \\
\hline $\mathrm{OM}$ & $20.7^{\mathrm{a}}$ & $23.2^{\mathrm{b}}$ & $21.4^{\mathrm{a}}$ & $21.7^{\mathrm{a}}$ & $23.6^{\mathrm{b}}$ & 0.7 & $<0.01$ \\
\hline Ether extract & $0.99^{\mathrm{a}}$ & $1.33^{\mathrm{b}}$ & $1.09^{\mathrm{c}}$ & $1.15^{\mathrm{c}}$ & $1.31^{\mathrm{b}}$ & 0.04 & $<0.01$ \\
\hline $\mathrm{NFC}^{2}$ & $6.9^{\mathrm{a}}$ & $6.7^{\mathrm{a}}$ & $6.8^{\mathrm{a}}$ & $6.5^{\mathrm{ab}}$ & $6.2^{\mathrm{b}}$ & 0.22 & 0.03 \\
\hline \multicolumn{8}{|l|}{ Digested, $\mathrm{kg} / \mathrm{d}$} \\
\hline DM & $13.8^{\mathrm{a}}$ & $14.7^{\mathrm{a}}$ & $14.9^{\mathrm{a}}$ & $14.3^{\mathrm{a}}$ & $16.3^{\mathrm{b}}$ & 0.5 & $<0.01$ \\
\hline $\mathrm{NDF}$ & $3.50^{\mathrm{a}}$ & $4.16^{\mathrm{b}}$ & $4.10^{\mathrm{b}}$ & $4.00^{\mathrm{b}}$ & $5.47^{\mathrm{c}}$ & 0.20 & $<0.01$ \\
\hline $\mathrm{N}$ & $0.46^{\mathrm{a}}$ & $0.49^{\mathrm{a}}$ & $0.48^{\mathrm{a}}$ & $0.47^{\mathrm{a}}$ & $0.58^{\mathrm{b}}$ & 0.02 & $<0.01$ \\
\hline $\mathrm{OM}$ & $13.3^{\mathrm{a}}$ & $14.2^{\mathrm{a}}$ & $14.3^{\mathrm{a}}$ & $13.8^{\mathrm{a}}$ & $15.7^{\mathrm{b}}$ & 0.5 & $<0.01$ \\
\hline Ether extract & $0.83^{\mathrm{a}}$ & $1.13^{\mathrm{b}}$ & $0.95^{\mathrm{c}}$ & $0.99^{\mathrm{c}}$ & $1.14^{\mathrm{b}}$ & 0.03 & $<0.01$ \\
\hline $\mathrm{NFC}$ & $6.2^{\mathrm{a}}$ & $5.9^{\mathrm{a}}$ & $6.3^{\mathrm{a}}$ & $5.9^{\mathrm{a}}$ & $5.5^{\mathrm{b}}$ & 0.2 & 0.01 \\
\hline \multicolumn{8}{|l|}{ Digestibility, \% } \\
\hline DM & $61.6^{\mathrm{ac}}$ & $58.8^{\mathrm{b}}$ & $63.6^{\mathrm{c}}$ & $60.7^{\mathrm{ab}}$ & $64.1^{\mathrm{c}}$ & 1.0 & $<0.01$ \\
\hline $\mathrm{NDF}$ & $41.9^{\mathrm{ab}}$ & $41.3^{\mathrm{a}}$ & $45.3^{\mathrm{b}}$ & $42.2^{\mathrm{ab}}$ & $50.7^{\mathrm{c}}$ & 1.5 & $<0.01$ \\
\hline $\mathrm{N}$ & $63.6^{\mathrm{ab}}$ & $61.5^{\mathrm{a}}$ & $65.3^{\mathrm{b}}$ & $62.9^{\mathrm{ab}}$ & $68.6^{\mathrm{c}}$ & 1.1 & $<0.01$ \\
\hline $\mathrm{OM}$ & $64.4^{\mathrm{ac}}$ & $61.6^{\mathrm{b}}$ & $66.5^{\mathrm{c}}$ & $63.6^{\mathrm{ab}}$ & $66.8^{\mathrm{c}}$ & 1.0 & $<0.01$ \\
\hline Ether extract & $83.7^{\mathrm{a}}$ & $84.6^{\mathrm{a}}$ & $86.8^{\mathrm{b}}$ & $85.9^{\mathrm{ab}}$ & $87.2^{\mathrm{b}}$ & 0.6 & $<0.01$ \\
\hline NFC & $89.4^{\mathrm{ac}}$ & $87.9^{\mathrm{a}}$ & $91.5^{\mathrm{b}}$ & $90.7^{\mathrm{c}}$ & $88.8^{\mathrm{a}}$ & 0.8 & $<0.01$ \\
\hline $\mathrm{TDN}^{3}, \%$ & $57.1^{\mathrm{a}}$ & $55.7^{\mathrm{a}}$ & $59.5^{\mathrm{b}}$ & $57.1^{\mathrm{a}}$ & $60.3^{\mathrm{b}}$ & 0.9 & 0.01 \\
\hline $\mathrm{NE}_{\mathrm{L}},{ }^{4} \mathrm{Mcal} / \mathrm{kg}$ & $1.32^{\mathrm{ab}}$ & $1.27^{\mathrm{a}}$ & $1.39^{\mathrm{bc}}$ & $1.32^{\mathrm{ab}}$ & $1.43^{\mathrm{c}}$ & 0.03 & $<0.01$ \\
\hline $\mathrm{NE}_{\mathrm{L}}$ intake, Mcal/d & $29.6^{\mathrm{a}}$ & $31.6^{\mathrm{ab}}$ & $32.6^{\mathrm{b}}$ & $31.0^{\mathrm{ab}}$ & $36.2^{\mathrm{c}}$ & 1.2 & $<0.01$ \\
\hline $\mathrm{EB},{ }^{5} \mathrm{Mcal} / \mathrm{d}$ & $0.54^{\mathrm{a}}$ & $0.77^{\mathrm{a}}$ & $2.51^{\mathrm{ab}}$ & $0.48^{\mathrm{a}}$ & $4.88^{\mathrm{b}}$ & 1.22 & $<0.01$ \\
\hline
\end{tabular}

${ }^{\mathrm{a}-\mathrm{c}}$ Means within a row with different superscripts differ $(P<0.05)$.

${ }^{1}$ Control $=0 \%$ of DM co-products; 15 WDGS $=15 \%$ of DM wet distillers grains with solubles (WDGS);

$15 \mathrm{WCGF}=15 \%$ of DM wet corn gluten feed (WCGF); $15 \mathrm{MIX}=7.5 \%$ of DM WDGS $+7.5 \%$ of DM WCGF;

$30 \mathrm{MIX}=15 \%$ of DM WDGS $+15 \%$ of DM WCGF.

${ }^{2} \mathrm{NFC}=100-(\mathrm{CP}+\mathrm{NDF}+$ ash + ether extract $)$.

${ }^{3}$ Total digestible nutrients $(\mathrm{TDN})=$ total digestible $(\mathrm{td}) \mathrm{NFC}+\mathrm{td} \mathrm{CP}+(\mathrm{td}$ ether extract $\times 2.25)+\mathrm{td} \mathrm{NDF}$

-7 (NRC, 2001).

${ }^{4} \mathrm{NE}_{\mathrm{L}}$ at actual intake based on TDN (NRC, 2001).

${ }^{5}$ Energy balance $(\mathrm{EB})=\mathrm{NE}_{\mathrm{L}}$ intake $(\mathrm{Mcal} / \mathrm{d})-\mathrm{NE}_{\mathrm{L}}$ milk $(\mathrm{Mcal} / \mathrm{d})-0.08 \mathrm{BW}^{0.75}$.

15WCGF (63.6\%), 15MIX (60.7\%), and 30MIX $(64.1 \%)$ and lower for 15WDGS (58.8\%) compared with control $(61.6 \%)$. These data suggest that the addition of $15 \%$ WCGF to the ration increased DMD compared with control whereas addition of $15 \%$ WDGS decreased DMD compared with control. In the rations containing co-products, NDF content was greater than control, and NDF digestibility (NDFD) was likely more important in determining DMD than in rations with lower concentrations of NDF. Total tract NDFD was higher $(P<0.01)$ for 30MIX $(50.7 \%)$ and similar for $15 \mathrm{WCGF}(45.3 \%)$, 15MIX (42.2\%), and 15WDGS (41.3\%) compared with control (41.9\%). The increased NDFD observed for 30MIX is likely attributable to replacing NDF from corn silage, alfalfa silage, and alfalfa hay with NDF from WDGS and WCGF. Getachew et al. (2004) measured in vitro NDFD of common ruminant feeds and found the coefficient of digestion for alfalfa silage (0.49), alfalfa hay (0.50), and corn silage
(0.42) to be similar to but lower than that of dried distillers grains with solubles (0.68). Miron et al. (2001) observed in vitro NDFD for dried distillers grains and corn gluten feed to be 76.5 and $83.4 \%$, respectively. Although not measured, rumen $\mathrm{pH}$ may have been higher for 30MIX because of low starch concentration in the ration, which may have improved digestion by cellulolytic bacteria and, therefore, NDF digestion (Grant and Mertens, 1992), allowing for increased DMI (Oba and Allen, 1999). Increased NDFD may have, in part, led to increased DMI for 30MIX.

Compared with control (63.6\%), $\mathrm{N}$ digestibility (Table 5) was higher $(P<0.01)$ for 30MIX $(68.6 \%)$ and similar for 15WCGF (65.3\%), 15MIX (62.9\%), and 15WDGS (61.5\%). The increased apparent N digestibility for 30MIX compared with control may be related to the increased NDF digestibility observed for 30MIX. Postruminal fermentation of NDF and other nutrients may stimulate microbial growth in the large intestine 
and increase $\mathrm{N}$ excretion of microbial products in feces, thus reducing apparent $\mathrm{N}$ digestibility (Van Soest, 1994).

Concentration of TDN (Table 5) was higher $(P=$ 0.01 ) for $15 \mathrm{WCGF}(59.5 \%)$ and 30MIX $(60.7 \%)$ and similar for 15WDGS (55.7\%) and 15MIX (57.1\%) compared with control $(57.1 \%)$. Total digestible nutrients were calculated based on nutrient digestibilities determined for each animal and treatment diet combination to account for the effect of DMI on digestibility. Effect of treatment diet on TDN largely mirrored that observed for DMD. Whereas DMI and TDN were increased for 30MIX compared with control, $4 \%$ FCM (Table 4) was not different among treatment diets, resulting in increased $(P<0.01)$ energy balance for 30MIX (4.88 Mcal/d) and similar for 15WDGS (0.77 $\mathrm{Mcal} / \mathrm{d}$ ), 15WCGF (2.51 Mcal/d), and 15MIX (0.48 Mcal/d) compared with control (0.54 Mcal/d).

\section{PD Excretion and Estimated Ruminal MCP Synthesis}

Excretion of urinary PD has been observed to be correlated to duodenal microbial N (Moorby et al., 2006). Purine derivative and estimated ruminal MCP production values are listed in Table 6. Daily urinary excretion of creatinine $(P=0.02)$ and uric acid $(P=$ $0.01)$ were higher for rations including co-products (15WDGS, 15WCGF, 15MIX, and 30MIX) than control, whereas allantoin and xanthine excretion were not different. Hypoxanthine excretion was greatest $(P<$ 0.01) for 30MIX, intermediate for 15WDGS, 15WCGF, and 15MIX, and lowest for control. When compared with control, total PD excretion was higher $(P=0.04)$ for all rations containing co-products. Because they are a prediction based on an algebraic equation and estimates of MCP contain only the error associated with measurement of urinary $\mathrm{PD}$, treatment diet differences for MCP synthesis should not be tested (Firkins et al., 2006). Nonetheless, MCP production was greater for 15WDGS, 15WCGF, 15MIX, and 30MIX than for control, suggesting that inclusion of co-products may have improved flow of MCP to the duodenum. Improved rumen conditions and greater ruminal nutrient supply may have stimulated rumen microbial growth and ultimately allowed for MCP synthesis to increase for rations containing co-products. In this study, some of the energy in starch from corn was replaced with energy from NDF in WDGS or WCGF. Reduced starch content and intake has been shown to increase rumen $\mathrm{pH}$ (Oba and Allen, 2003), and increasing rumen $\mathrm{pH}$ from low and acidic levels has been shown to stimulate MCP synthesis (Calsamiglia et al., 2008). The NRC (2001) model predicts MCP synthesis based on TDN intake. It should be noted that the relationship between TDN intake and MCP for this experiment is inconsistent. For 30MIX, increased intake of TDN and amount of DM apparently digested corresponds to increased MCP compared with control. However, for the other treatment diets including co-products, TDN intake and apparently digested DM were similar compared with control but calculated MCP synthesis increased. The large differences in MCP synthesis and relatively smaller differences in TDN among treatment diets indicates that other nutritional factors, such as the effect of carbohydrate degradation rate in the rumen and the effect of starch intake on rumen $\mathrm{pH}$, may have influenced the calculated increase in MCP to a greater degree than TDN.

Table 6. Effects of feeding corn milling co-products on urinary excretion of purine derivatives and estimation of ruminal microbial crude protein (MCP) synthesis

\begin{tabular}{|c|c|c|c|c|c|c|c|}
\hline \multirow{2}{*}{$\begin{array}{l}\text { Item, mmol/d } \\
\text { unless noted }\end{array}$} & \multicolumn{5}{|c|}{ Diet $^{1}$} & \multirow[b]{2}{*}{ SEM } & \multirow[b]{2}{*}{$P$-value } \\
\hline & Control & 15WDGS & 15WCGF & $15 \mathrm{MIX}$ & 30MIX & & \\
\hline Creatinine & $156.1^{\mathrm{a}}$ & $158.9^{\mathrm{b}}$ & $158.3^{\mathrm{b}}$ & $158.3^{\mathrm{b}}$ & $158.5^{\mathrm{b}}$ & 2.5 & 0.02 \\
\hline Allantoin & 302.4 & 330.8 & 321.9 & 331.8 & 334.6 & 10.3 & 0.10 \\
\hline Uric acid & $58.4^{\mathrm{a}}$ & $65.9^{\mathrm{b}}$ & $65.4^{\mathrm{b}}$ & $67.9^{\mathrm{b}}$ & $65.9^{\mathrm{b}}$ & 2.8 & 0.01 \\
\hline Hypoxanthine & $15.6^{\mathrm{a}}$ & $25.6^{\mathrm{b}}$ & $26.5^{\mathrm{b}}$ & $28.4^{\mathrm{bc}}$ & $31.6^{\mathrm{c}}$ & 2.0 & $<0.01$ \\
\hline Xanthine & 37.4 & 44.7 & 64.7 & 26.3 & 37.8 & 14.9 & 0.25 \\
\hline Purine derivatives ${ }^{2}$ & $414.3^{\mathrm{a}}$ & $467.1^{\mathrm{b}}$ & $478.6^{\mathrm{b}}$ & $454.3^{\mathrm{b}}$ & $469.9^{\mathrm{b}}$ & 17.8 & 0.04 \\
\hline $\mathrm{MCP}, 3 \mathrm{~g} / \mathrm{d}$ & $1,745.1$ & $1,994.3$ & $2,049.9$ & $1,934.2$ & $2,008.2$ & - & - \\
\hline
\end{tabular}

${ }^{\mathrm{a}-\mathrm{c}}$ Means within a row with different superscripts differ $(P<0.05)$.

${ }^{1}$ Control $=0 \%$ of DM co-products; $15 \mathrm{WDGS}=15 \%$ of DM wet distillers grains with solubles (WDGS); $15 \mathrm{WCGF}=15 \%$ of DM wet corn gluten feed (WCGF); $15 \mathrm{MIX}=7.5 \%$ of DM WDGS $+7.5 \%$ of DM WCGF; $30 \mathrm{MIX}=15 \%$ of DM WDGS $+15 \%$ of DM WCGF.

${ }^{2}$ Purine derivatives calculated as allantoin + uric acid + hypoxanthine + xanthine.

${ }^{3}$ Microbial CP synthesis calculated as described by Chen and Gomes (1992). Statistical test of effect of treatment diet on ruminal microbial CP synthesis was not conducted because microbial CP was calculated based on excretion of PD (Firkins et al., 2006). 
Table 7. Effects of feeding corn milling co-products on $\mathrm{N}$ utilization

\begin{tabular}{|c|c|c|c|c|c|c|c|}
\hline \multirow[b]{2}{*}{ Item } & \multicolumn{5}{|c|}{$\operatorname{Diet}^{1}$} & \multirow[b]{2}{*}{ SEM } & \multirow[b]{2}{*}{$P$-value } \\
\hline & Control & 15WDGS & 15WCGF & 15MIX & 30MIX & & \\
\hline \multicolumn{8}{|l|}{ Mass, $\mathrm{g} / \mathrm{d}$} \\
\hline Intake N & $725.1^{\mathrm{a}}$ & $799.2^{\mathrm{b}}$ & $732.1^{\mathrm{a}}$ & $747.0^{\mathrm{a}}$ & $840.9^{\mathrm{b}}$ & 24.1 & $<0.01$ \\
\hline Fecal N & $264.9^{\mathrm{a}}$ & $311.0^{\mathrm{b}}$ & $248.9^{\mathrm{a}}$ & $275.7^{\mathrm{a}}$ & $263.8^{\mathrm{a}}$ & 11.8 & $<0.01$ \\
\hline Urinary $\mathrm{N}$ & $308.5^{\mathrm{a}}$ & $312.2^{\mathrm{a}}$ & $319.3^{\mathrm{ab}}$ & $320.5^{\mathrm{ab}}$ & $330.0^{\mathrm{b}}$ & 7.4 & 0.03 \\
\hline Manure $\mathrm{N}^{2}$ & $571.9^{\mathrm{a}}$ & $623.2^{\mathrm{b}}$ & $567.8^{\mathrm{a}}$ & $596.2^{\mathrm{ab}}$ & $593.8^{\mathrm{ab}}$ & 16.2 & 0.04 \\
\hline Milk N ${ }^{3}$ & $192.3^{\mathrm{a}}$ & $200.9^{\mathrm{bc}}$ & $196.9^{\mathrm{ab}}$ & $201.2^{\mathrm{bc}}$ & $206.4^{\mathrm{c}}$ & 5.4 & 0.06 \\
\hline Retained $\mathrm{N}^{4}$ & $-39.3^{\mathrm{a}}$ & $-24.9^{\mathrm{a}}$ & $-32.6^{\mathrm{a}}$ & $-50.4^{\mathrm{a}}$ & $40.7^{\mathrm{b}}$ & 14.6 & $<0.01$ \\
\hline Productive $\mathrm{N}^{5}$ & $153.4^{\mathrm{a}}$ & $176.0^{\mathrm{a}}$ & $164.4^{\mathrm{a}}$ & $150.8^{\mathrm{a}}$ & $247.1^{\mathrm{b}}$ & 15.8 & $<0.01$ \\
\hline \multicolumn{8}{|l|}{$\mathrm{N}$ intake, \% } \\
\hline Fecal N & $36.5^{\mathrm{ab}}$ & $38.5^{\mathrm{a}}$ & $34.7^{\mathrm{b}}$ & $37.1^{\mathrm{ab}}$ & $31.4^{\mathrm{c}}$ & 1.0 & $<0.01$ \\
\hline Urinary $\mathrm{N}$ & $43.0^{\mathrm{ab}}$ & $40.3^{\mathrm{ac}}$ & $45.0^{\mathrm{b}}$ & $44.2^{\mathrm{b}}$ & $39.9^{\mathrm{c}}$ & 1.2 & $<0.01$ \\
\hline Manure N & $79.3^{\mathrm{a}}$ & $78.7^{\mathrm{a}}$ & $78.3^{\mathrm{a}}$ & $80.4^{\mathrm{a}}$ & $71.2^{\mathrm{b}}$ & 1.5 & $<0.01$ \\
\hline Milk N & $26.7^{\mathrm{a}}$ & $26.2^{\mathrm{a}}$ & $27.5^{\mathrm{a}}$ & $27.8^{\mathrm{a}}$ & $24.5^{\mathrm{b}}$ & 0.8 & 0.01 \\
\hline Retained N & $-6.2^{\mathrm{a}}$ & $-4.9^{\mathrm{a}}$ & $-7.2^{\mathrm{a}}$ & $-9.2^{\mathrm{a}}$ & $4.1^{\mathrm{b}}$ & 2.1 & $<0.01$ \\
\hline Productive N & $20.6^{\mathrm{a}}$ & $21.3^{\mathrm{a}}$ & $20.3^{\mathrm{a}}$ & $18.7^{\mathrm{a}}$ & $28.6^{\mathrm{b}}$ & 1.7 & $<0.01$ \\
\hline
\end{tabular}

${ }^{\mathrm{a}-\mathrm{c}}$ Means within a row with different superscripts differ $(P<0.05)$.

${ }^{1}$ Control $=0 \%$ of DM co-products; $15 \mathrm{WDGS}=15 \%$ of DM wet distillers grains with solubles (WDGS);

$15 \mathrm{WCGF}=15 \%$ of DM wet corn gluten feed (WCGF); $15 \mathrm{MIX}=7.5 \%$ of DM WDGS $+7.5 \%$ of DM WCGF; $30 \mathrm{MIX}=15 \%$ of DM WDGS $+15 \%$ of DM WCGF .

${ }^{2}$ Manure $\mathrm{N}=$ fecal $\mathrm{N}+$ urinary $\mathrm{N}$.

${ }^{3}$ Milk $\mathrm{N}=$ milk protein yield $/ 6.38$.

${ }^{4}$ Retained $\mathrm{N}=$ intake $\mathrm{N}-($ manure $\mathrm{N}+$ milk $\mathrm{N})$.

${ }^{5}$ Productive $\mathrm{N}=$ milk $\mathrm{N}+$ retained $\mathrm{N}$.

The concentration of urinary hypoxanthine was higher for rations that included distillers grains with solubles, as was also observed by Janicek et al. (2008) and Kelzer (2008). The central assumption when using $\mathrm{PD}$ as an MCP marker is the complete degradation of feed purines in the rumen and the absorption of purines solely from microbial origin (Chen and Gomes, 1992). Yeast cells present in the co-products may be undegradable in the rumen because of heating during the corn milling process, resulting in digestion and absorption of purines from yeast cells and increased hypoxanthine excretion. As a consequence, MCP synthesis may be overestimated and caution should be taken when interpreting MCP synthesis when estimated by urinary PD excretion.

\section{N Utilization}

In this study, cows consuming 30MIX were observed to have increased $(P<0.01) \mathrm{N}$ intake and retention while maintaining similar manure $\mathrm{N}$ (fecal + urinary $\mathrm{N}$ ) excretion compared with control (Table 7). When expressed as a percentage of $\mathrm{N}$ intake, cows consuming 30MIX excreted a lower $(P<0.01)$ proportion of intake $\mathrm{N}$ in manure compared with cows consuming control $(71.2$ vs. $79.3 \%)$. This resulted in the observed increase in calculated retained $\mathrm{N}$ both as a total mass (40.7 vs. $-39.3 \mathrm{~g} / \mathrm{d}$ ) and as a proportion of $\mathrm{N}$ intake (4.1 vs.
$-6.2 \%$ ) for 30MIX compared with control, as observed by others for treatment diets resulting in increased $\mathrm{N}$ intake (Wattiaux and Karg, 2004). The only measured evidence of increased $\mathrm{N}$ retention was increased $\mathrm{BW}$, but no difference in BCS was observed between control and 30MIX (averaging $3.14 \pm 0.07$; Table 4). The observed increase in calculated $\mathrm{N}$ retention for 30MIX but lack of significant difference in BCS may be related to a lack of precision in BCS estimates or potential overestimation of $\mathrm{N}$ balance. Whereas total manure $\mathrm{N}$ excretion was similar for 30MIX and control, urinary N was increased for 30MIX. This effect may be considered to be a negative environmental effect because urinary $\mathrm{N}$ is rapidly converted to ammonia, which is recognized as a notable air pollutant (Bussink and Oenema, 1998). Route of $\mathrm{N}$ excretion is mediated by $\mathrm{N}$ intake, with excess $\mathrm{N}$ primarily excreted via urine (Kebreab et al., 2001). The reason for the increased urinary $\mathrm{N}$ for 30MIX was likely related to incomplete conversion of absorbed AA provided by 30MIX into milk or body protein (Tamminga, 1992) because of AA supply exceeding requirement. Whereas $\mathrm{N}$ excretion was not reduced with 30MIX compared with other treatment diets as hypothesized, it was similar to control despite increased $\mathrm{N}$ intake. This suggests feeding both WDGS and WCGF together may allow for greater total inclusion of co-products without negatively affecting $\mathrm{N}$ excretion. Compared with 15WDGS, 30MIX resulted 
in greater retention of intake $\mathrm{N}$, indicating that the addition of WCGF to the ration containing WDGS improved $\mathrm{N}$ utilization.

In contrast to 30MIX, increased $\mathrm{N}$ intake observed for 15WDGS compared with control resulted in greater manure $\mathrm{N}$ excretion attributed to increased fecal $\mathrm{N}$ excretion. Nitrogen digestibility was similar for 15 WDGS compared with control whereas $\mathrm{N}$ intake was increased, resulting in increased fecal $\mathrm{N}$ excretion. The RUP from WDGS has been found to be highly digestible (93.1\%; Kelzer, 2008). Rations containing WDGS would presumably contain higher levels of RUP but would not be expected to result in higher fecal $\mathrm{N}$ when $\mathrm{N}$ intake is similar (Davidson et al., 2003). Increased fecal N observed for rations with high RUP may be attributed to increased DMI stimulated by RUP, resulting in higher $\mathrm{N}$ intake, but not attributed to excretion of undigested feed protein (Flis and Wattiaux, 2005). Others have observed increased fecal $\mathrm{N}$ with increased $\mathrm{N}$ intake (Broderick, 2003; Groff and Wu, 2005; Ipharraguerre and Clark, 2005).

\section{Milk Production and Components}

Production of milk and its components is listed in Table 4. Actual milk production was greater $(P=0.02)$ for 15WDGS, 15MIX, and 30MIX (41.2, 41.9, and 41.8 $\mathrm{kg} / \mathrm{d}$ ) and similar for 15WCGF (40.4 kg/d) compared with control $(38.6 \mathrm{~kg} / \mathrm{d})$. There were no differences among treatment diets for $4 \% \mathrm{FCM}$, fat concentration or yield, protein concentration, or MUN, averaging $40.4 \pm 1.2 \mathrm{~kg} / \mathrm{d}, 3.94 \pm 0.09 \%, 1.45 \pm 0.05 \mathrm{~kg} / \mathrm{d}, 3.02$ $\pm 0.03 \%$, and $14.5 \pm 0.3 \mathrm{mg} / \mathrm{dL}$, respectively. Milk protein yield was greater $(P=0.02)$ for 15WDGS, 15MIX, and 30MIX $(1.26,1.26$, and $1.29 \mathrm{~kg} / \mathrm{d})$ but similar to 15 WCGF $(1.22 \mathrm{~kg} / \mathrm{d})$ compared with control $(1.16 \mathrm{~kg} / \mathrm{d})$. Because of increased DMI with a relatively smaller increase in milk production, feed conversion tended to be lower $(P=0.10)$ for animals consuming 30MIX (1.63), similar for 15WDGS (1.70), and higher for 15WCGF (1.79) and 15MIX (1.77) compared with control (1.74).

Previous studies have reported an increase in milk production when cows were fed rations with $40 \%$ WCGF compared with a zero control with no negative effects on milk components (Boddugari et al., 2001; Kononoff et al., 2006). These results are similar to other research evaluating either wet or dry distillers grains with solubles (Anderson et al., 2006; Janicek et al., 2008). In the current study, responses in actual milk production closely mirrored differences in DMI and were higher for all rations including WDGS (15WDGS, 15MIX, and 30MIX), whereas 15WCGF showed similar milk production without an increase in DMI. The relationship between milk production and intake of $\mathrm{NE}_{\mathrm{L}}$ was inconsistent. Compared with control, 30MIX resulted in both increased $\mathrm{NE}_{\mathrm{L}}$ intake and milk production, 15WCGF had greater $\mathrm{NE}_{\mathrm{L}}$ intake but similar production, and 15WDGS and 15MIX had similar $\mathrm{NE}_{\mathrm{L}}$ intake and greater production. Whereas it was hypothesized that both MCP and RUP flow would increase when WDGS and WCGF were fed together, there were only small differences in RUP content of the rations as estimated by NRC (2001): 7.7 to $8.5 \%$ of DM. This is in part because a portion of bypass soybean meal was replaced with WDGS and WCGF, resulting in similar RUP content among rations. However, MP flow may have still been increased with rations containing co-products because of the observed increase in MCP synthesis, and this may have resulted in the observed increase in milk protein yield (Vagnoni and Broderick, 1997). Because of a numeric decrease in milk fat concentration when fed co-products, $4 \%$ FCM was not different among treatment diets. Whereas cows consuming 30MIX consumed more feed that was more digestible, resulting in higher energy intake than other treatment diets, this did not affect FCM production. It bears noting that rations with co-products had low starch and NFC content (Table 3) while maintaining similar 4\% FCM as control. Nocek (1997) recommends limiting NFC in dairy rations to 30 to $40 \% \mathrm{DM}$ to avoid acidosis. In this study, diets containing 17 to $20 \%$ starch and increased content of digestible fiber and fat were able to maintain milk production compared with a diet containing $24 \%$ starch. Whereas DMI, nutrient digestibility, and $\mathrm{N}$ utilization were improved for 30MIX, there was no difference in $4 \%$ FCM. Whereas ruminal MCP synthesis was increased with co-product rations, indicating an increase in overall MP supply, this did not result in increased 4\% FCM as hypothesized. The effect of treatment diet on energy balance and $\mathrm{N}$ retention over the long term may result in improved reproduction, health, or lifetime milk production.

\section{CONCLUSIONS}

A ration containing 30\% corn milling co-products (15\% WDGS and 15\% WCGF) resulted in greater DMI than a ration not containing corn milling co-products. Dry matter digestibility was similar, whereas NDF and $\mathrm{N}$ digestibility and TDN was increased for the ration including 30\% co-products. Excretion of PD increased when cows were fed a ration containing $30 \%$ of the ration $\mathrm{DM}$ as co-product, suggesting that feeding it may increase MCP flow to the small intestine. Nitrogen excretion was highest when WDGS was included in the ration at $15 \%$ because of increased fecal $\mathrm{N}$ excretion. Fat-corrected milk production was not different among 
treatment diets. Compared with the ration containing WDGS, the ration with a $30 \%$ mixture of WDGS and WCGF improved nutrient digestibility and $\mathrm{N}$ utilization, with reduced manure $\mathrm{N}$ excretion and increased $\mathrm{N}$ retention. Thus, it appears that feeding WDGS and WCGF in combination reduces some of the negative effects of feeding WDGS alone.

\section{ACKNOWLEDGMENTS}

The authors thank the Nebraska Corn Board (Lincoln) for financial support. The authors also thank the personnel at the University of Nebraska Dairy Unit for care of the experimental animals and C. Mullins, Z. Alger, J. Warner, B. Janicek, and J. Kelzer of the University of Nebraska-Lincoln for sampling and laboratory assistance.

\section{REFERENCES}

Allen, M. S. 2000. Effects of diet on short-term regulation of feed intake by lactating dairy cattle. J. Dairy Sci. 83:1568-1624.

Anderson, J. L., D. J. Schingoethe, K. F. Kalscheur, and A. R. Hippen. 2006. Evaluation of dried and wet distillers grains included at two concentrations in the diets of lactating dairy cows. J. Dairy Sci. $89: 3133-3142$.

AOAC. 2000. Official Methods of Analysis. Vol. 1 and 2. 17th ed. AOAC Int., Gaithersburg, MD.

Boddugari, K., R. J. Grant, R. Stock, and M. Lewis. 2001. Maximal replacement of forage and concentrate with a new wet corn milling product for lactating dairy cows. J. Dairy Sci. 84:873-884.

Boston, R. C., D. G. Fox, C. J. Sniffen, R. Janczewski, R. Munsen, and W. Chalupa. 2000. The conversion of a scientific model describing dairy cow nutrition and production to an industry tool: The CPM Dairy project. Pages 361-377 in Modelling Nutrient Utilization in Farm Animals. J. P. McNamara, J. France, and D. Beever, ed. CABI Publishing, Oxford, UK.

Bothast, R. J., and M. A. Schlicher. 2005. Biotechnological processes for conversion of corn into ethanol. Appl. Microbiol. Biotechnol. $67: 19-25$.

Broderick, G. A. 2003. Effects of varying dietary protein and energy levels on the production of lactating dairy cows. J. Dairy Sci. 86:1370-1381.

Bussink, D. W., and O. Oenema. 1998. Ammonia volatilization from dairy farming systems in temperate areas: A review. Nutr. Cycl. Agroecosyst. 51:19-33.

Calsamiglia, S., P. W. Cardozo, A. Ferret, and A. Bach. 2008. Changes in rumen microbial fermentation are due to a combined effect of type of diet and pH. J. Anim. Sci. 86:702-711.

Chen, X. B., and M. J. Gomes. 1992. Estimation of microbial protein supply to sheep and cattle based on urinary excretion of purine derivatives - An overview of the technical details. Rowett Research Institute, Bucksburn, Aberdeen, UK.

Clark, J. H., T. H. Klusmeyer, and M. R. Cameron. 1992. Microbial protein synthesis and flows of nitrogen fractions to the duodenum of dairy cows. J. Dairy Sci. 75:2304-2323.

Davidson, S., B. A. Hopkins, D. E. Diaz, S. M. Bolt, C. Brownie, V. Fellner, and L. W. Whitlow. 2003. Effects of amounts and degradability of dietary protein on lactation, nitrogen utilization, and excretion in early lactation Holstein cows. J. Dairy Sci. $86: 1681-1689$

Firkins, J. L., A. N. Hristov, M. B. Hall, G. A. Varga, and N. R. StPierre. 2006. Integration of ruminal metabolism in dairy cattle. J. Dairy Sci. 89:E31-E51.
Flis, S. A., and M. A. Wattiaux. 2005. Effects of parity and supply of rumen-degraded and undegraded protein on production and nitrogen balance in Holsteins. J. Dairy Sci. 88:2096-2106.

Getachew, G., P. H. Robinson, E. J. DePeters, and S. J. Taylor. 2004. Relationships between chemical composition, dry matter degradation and in vitro gas production of several ruminant feeds. Anim. Feed Sci. Technol. 111:57-71.

Gonda, H. L. 1995. Nutritional status of ruminants determined from excretion and concentration of metabolites in body fluids. PhD Diss. Dep. Anim. Nutr. and Management, Swedish Univ. of Agricultural Sciences, Uppsala.

Grant, R. J., and D. R. Mertens. 1992. Development of buffer systems for $\mathrm{pH}$ control and evaluation of $\mathrm{pH}$ effects on fiber digestion in vitro. J. Dairy Sci. 75:1581-1587.

Groff, E. B., and Z. Wu. 2005. Milk production and nitrogen excretion of dairy cows fed different amounts of protein and varying proportion of alfalfa and corn silage. J. Dairy Sci. 88:3619-3632.

Harvatine, K. J., and M. S. Allen. 2006. Effects of fatty acid supplement on ruminal and total tract nutrient digestion in lactating dairy cows. J. Dairy Sci. 89:1092-1103.

Heinrichs, A. J., and P. J. Kononoff. 2002. Evaluating particle size of forages and TMRs using the new Penn State Forage Particle Separator. Tech. Bull. DAS 02-42. College Agric. Sci., Cooperative Ext., Pennsylvania State Univ., University Park.

Huhtanen, P., K. Kaustell, and S. Jaakkola. 1994. The use of internal markers to predict total digestibility and duodenal flow of nutrients in cattle given six different diets. Anim. Feed Sci. Technol. 48:211-227.

Ipharraguerre, I. R., and J. H. Clark. 2005. Varying protein and starch in the diet of dairy cows: II. Effects on performance and nitrogen utilization for milk production. J. Dairy Sci. 88:2556-2570.

Ivan, S. K., H. L. Haugen, and T. J. Klopfenstein. 2004. Utilization of the mobile bag technique to determine intestinal digestibility of feedstuffs. J. Dairy Sci. 87(Suppl. 1):214.

Janicek, B. N., P. J. Kononoff, A. M. Gehman, and P. H. Doane. 2008. The effect of feeding dried distillers grains plus soluble on milk production and excretion of urinary purine derivatives. J. Dairy Sci. 91:3544-3553.

Kebreab, E., J. France, D. E. Beever, and A. R. Castillo. 2001 Nitrogen pollution by dairy cows and its mitigation by dietary manipulation. Nutr. Cycl. Agroecosyst. 60:275-285.

Kelzer, J. M. 2008. Effects of feeding three types of corn milling coproducts on milk production and ruminal fermentation of lactating Holstein cattle. MS Thesis. Univ. of Nebraska, Lincoln.

Kononoff, P. J., S. K. Ivan, W. Matzke, R. J. Grant, R. A. Stock, and T. J. Klopfenstein. 2006. Milk production of dairy cows fed a wet corn gluten feed during the dry period and lactation. J. Dairy Sci. 89:2608-2617.

Leonardi, C., M. Stevenson, and L. E. Armentano. 2003. Effect of two levels of crude protein and methionine supplementation on performance of dairy cows. J. Dairy Sci. 86:4033-4042.

Miron, J., E. Yosef, and D. Ben-Ghedalia. 2001. Composition and in vitro digestibility of monosaccharide constituents of selected byproduct feeds. J. Agric. Food Chem. 49:2322-2326.

Moorby, J. M., R. J. Dewhurst, R. T. Evans, and J. L. Danelon. 2006 Effects of dairy cow diet forage proportion on duodenal nutrient supply and urinary purine derivative excretion. J. Dairy Sci. 89:3552-3562.

National Research Council. 2001. Nutrient Requirements of Dairy Cattle. 7th rev ed. National Academy Press, Washington, DC.

Nocek, J. E. 1997. Bovine acidosis: Implications on laminitis. J. Dairy Sci. 80:1005-1028.

Oba, M., and M. S. Allen. 1999. Evaluation of the importance of the digestibility of neutral detergent fiber from forage: Effects on dry matter intake and milk yield of dairy cows. J. Dairy Sci. 82:589-596.

Oba, M., and M. S. Allen. 2003. Effects of diet fermentability on efficiency of microbial nitrogen production in lactating dairy cows. J. Dairy Sci. 86:196-207. 
Oldick, B. S., and J. L. Firkins. 2000. Effects of degree of fat saturation on fiber digestibility and microbial protein synthesis when diets are fed twelve times daily. J. Anim. Sci. 78:2412-2420.

Pereira, M. N., E. F. Garrett, G. R. Oetzel, and L. E. Armentanto. 1999. Partial replacement of forage with nonforage fiber sources in lactating cow diets. I. Performance and health. J. Dairy Sci. $82: 2716-2730$.

SAS Institute. 2004. SAS/STAT User's Guide. Version 9.1. SAS Institute Inc., Cary, NC.

Schingoethe, D. J., M. J. Brouk, and C. P. Birkelo. 1999. Milk production and composition from cows fed wet corn distillers grains. J. Dairy Sci. 82:574-580.

Shingfield, K. J., and N. W. Offer. 1998. Evaluation of milk allantoin excretion as an index of microbial protein supply in lactating dairy cows. Anim. Sci. 67:371-385.

Shingfield, K. J., and N. W. Offer. 1999. Simultaneous determination of purine metabolites, creatinine, and pseudouridine in ruminant urine by reversed-phase high-performance liquid chromatography. J. Chromatogr. B Analyt. Technol. Biomed. Life Sci. 723:81-94.

Tamminga, S. 1992. Nutrition management of dairy cows as a contribution to pollution control. J. Dairy Sci. 75:345-357.
Vagnoni, D. B., and G. A. Broderick. 1997. Effects of supplementation of energy or ruminally undegraded protein to lactating cows fed alfalfa hay or silage. J. Dairy Sci. 80:1703-1712.

Valadares, R. F. D., G. A. Broderick, S. C. Valadares Filho, and M. K. Clayton. 1999. Effect of replacing alfalfa silage with high moisture corn on ruminal protein synthesis estimated from excretion of total purine derivatives. J. Dairy Sci. 82:2686-2696.

Van Soest, P. J. 1994. Nutritional Ecology of the Ruminant. 2nd ed. Cornell University Press, Ithaca, NY.

Wattiaux, M. A., and K. L. Karg. 2004. Protein level for alfalfa and corn-silage based diets: II. Nitrogen balance and manure characteristics. J. Dairy Sci. 87:3492-3502.

Whittet, K. M. 2004. Factors affecting variability in urinary creatinine and purine derivative excretion in beef cattle. MS Thesis. Univ. of Nebraska, Lincoln.

Wildman, E. E., G. M. Jones, P. E. Wagner, H. F. Troutt, and T. N. Lesch. 1982. A dairy cow body condition scoring system and its relationship to selected production characteristics. J. Dairy Sci. 65:495-501. 